\title{
PLS-SEM Based Analysis of Service Quality and Satisfaction in Open Distance Learning in Sri Lanka
}

\author{
M. J. Renuka Perera ${ }^{1}$, Gapar M. Johar ${ }^{1}$, Ali Kathibi ${ }^{1}$, Halinah Atan ${ }^{1}$, Nalin Abeysekera ${ }^{2} \&$ Isuri R. \\ Dharmaratne $^{1}$ \\ ${ }^{1}$ Management \& Science University, Malaysia \\ ${ }^{2}$ Open University of Sri Lanka, Sri Lanka \\ Correspondence: M. J. Renuka Perera, Management \& Science University, Malaysia. E-mail: \\ renukapousl@gmail.com
}

Received: August 20, 2017

Accepted: September 20, 2017

Online Published: October 18, 2017

doi:10.5539/ijbm.v12n11p194

URL: https://doi.org/10.5539/ijbm.v12n11p194

\begin{abstract}
Students' Perceived Service Quality (SPSQ) and Students' Satisfaction (SSAT) in Open Distance Learning (ODL) are renowned features in Higher Education (HE) field in the present-day. The vast number of research studies have addressed diverse types of variables on different grounds. The ODL students are from various family backgrounds such as cultural, social, technological skill levels, and most importantly defer from basic educational entry qualifications. This must cognize how the HE institutions are able to offer their diversified services together with quality enhanced features to enjoy a competitive edge from the student's satisfaction point of view. The number of students completing the course, or graduates passing out are diminishing when compared with the increase in number of registered student's year on year. Most of the universities and HE institutions have faced student persistence and attrition problems and rush to find solutions with the concepts of service quality and satisfaction. The purpose of this study is mainly based on finding out the significant factors affecting the SPSQ and SSAT. This study will address the modified SERVQUAL constructs in relation to the SPSQ and SSAT. The independent variables were Assurance, Empathy, Responsiveness, Reliability, and Website Content and the dependent variables were the Students' Perceived Service Quality and Satisfaction in ODL in the OUSL. Data was collected by using a self-administered questionnaire from 760 undergraduate students of the Open University of Sri Lanka (OUSL) covering six main regional centers island wide. The OUSL is the unique university operating under the ODL system in Sri Lanka. The analysis was based on descriptive and inferential statistics. The significant relationships are revealed between the SPSQ and Reliability, Responsiveness and Website Content. The other significant relationships are SSAT with Reliability and Website Content and the relationship between SPSQ and SSAT. The $\mathrm{R}^{2}$ for the SPSQ is $0.244(24 \%)$ and SSAT is $0.549(55 \%)$. The same research could be recommended as a future research with more service quality variables, and in regional centers as a longitudinal data collection method to understand more about service quality and satisfaction which influence student retention and completion.
\end{abstract}

Keywords: attrition, open distance learning, persistence, satisfaction, service quality, significant, quality

\section{Introduction}

Service Quality and Student Satisfaction in Open Distance Learning (ODL) are becoming more important day by day with the increasing demand of higher education sector. Distance Education (DE) has formed as a supplement method of teaching and learning process over the world. The distance education is defined as a mode of teaching and learning characterized by separation of teacher and learner in time and/or place for most part of the educational transaction, mediated by technology for delivery of learning content with possibility of face-to-face interaction for learner-teacher and learner-learner interaction, provision of two-way didactic communication, and acceptance of industrial process for division of labour, and economies of scale (Open and Distance Learning Key Terms \& Definitions Commonwealth of Learning CC BY SA, June 2015).

ODL denotes no barriers for the enrollment of university education on entry qualifications, age or location. "It should be understood that students in ODL operate in contextually different academic and social environments than those in conventional settings" (Chakuchichi, 2011, p. 90). The ODL environment is benevolent many advantages, the expected results of graduated output or completion rate could not be reached. The students who 
are graduating with ODL system with higher education qualifications they will able to use that qualifications to gain higher remunerations (Simpson, E-Learning and the Future of Distance Education, 2013). The theory of student integration by Tinto in 2008 as cited by (Jones D. , 2009 ) " The time of adjustment for a student to their new environment is a time of risk for withdrawal as students may suffer stress and a sense of loss". The problem of student attrition or dropouts has to be solved by the universities or the higher education institutes. The Open University of Sri Lanka also has faced the same situation of high dropouts of registered students (Statistical Handbook 2013, 2014; Strategic Management Plan 2015 - 2020, 2014). The factors influencing for high dropout rates in OUSL faculty of engineering identified as mismatch with the expectations and entry qualifications, old-employed learners, difficult to update the knowledge with latest technologies, poor language proficiencies, physical distance and jobs and family constrains (Liyanagama, 2014). Consequently in 2009 Jones has uncovered the reasons for the student attrition as selection of the wrong course, lack of timely support/course information, isolation, unbearable workload with assignments and assesment criteria. The 'rivergram' has showed the dropouts of the students of their first course in Open University of United Kingdom (UKOU) and Distance student must be given the support in various time in their learning journey (Simpson, Student Support Service for Success in Open and Distance Learning, Feb 17, 2016).

Whether the students need more support or few , helping a student will be more effective to overcome their problems and reached to thier expected porgress (Simpson, Student Support Service for Success in Open and Distance Learning, Feb 17, 2016). "The quality factors were strongly linked to academic progress which closely related to student retention" (Chakuchichi, 2011, p. 90). The Perceived service quality is defined as" an overall evaluation of the goodness or badness of a product or service" or as an attitude. The consumer satisfaction is "similar to attitude, but it is short-term and results from an evaluation of a specific consumption experience" (Athiyaman, 1997). "Delivering of quality service has become an important goal for most higher education institutions" (Athiyaman, 1997, p. 539). The student retention is defined as "the act of retaining or keeping students on the programme until its natural conclusion or they have achieved their academic goals" (Chakuchichi, 2011, p. 90; Jones, Berry, Gregson, \& Smith, 2008). "For the ODL institutions to improve quality of service provision in order to manage student retention. In seeking to improve student retention ODL institutions could work out intervention strategies that impact quality instruction, information computer technology and the economies of scale regarding affordability of education" (Chakuchichi, 2011, p. 97). The high noncompletion rate recorded from the OUSL in very popular programme of Certificate in Preschool Education. The recommended solution was given to minimize this situation was to enhance the quality perspectives and effectiveness of the program (Ariyaratne, Munasinghe, Seneviratne, Rajapaksha, \& Dediwala, 2014).

\subsection{Problem Statement}

It has been evident that the completion rate of the registered courses are very low in comparison to the student enrollment rate in the Open University of Sri Lanka (Statistical Handbook - 2013- Open University of Sri Lanka (OUSL), July 2014) and consequently the student dropout or attrition rate is extremely high (Strategic Management Plan 2015 - 2020, 2014). The said low level graduation rate and low continuity rates are serious concerns. Researchers have predicted many reasons and recommendations (Ariyaratne, Munasinghe, Seneviratne, Rajapaksha, \& Dediwala, 2014; Ismail, 1997 August; De Zoysa, Munasinghe, Seneviratne, \& Mukunthan, 2011; Liyanagama, 2014). The deficiencies in offered service by the institution and perceived by the students is one of the main reason and empirically has proven which will lead to student satisfaction or dissatisfaction (Jurkowitsch, Vignali, \& Kaufmann, 2006 ). In marketing perspectives the consumer perceived service quality, satisfaction and behavioral literature has been used to ascertain the customer service quality and satisfaction (Cronin \& Taylor, 1992; Parasuraman, Zeithaml, \& Berry., 1988; Parasuraman, Zeithaml, \& Malhotra, 2005; ZeithamI, Berry, \& Parasuraman, 1996). In the higher education enviornment the most famous validated instrument of SERVQUAL (Parasuraman, Zeithaml, \& Berry., 1988) has applied these service quality concepts in various higher educational research studies ( (Mbwesa, 2014; Ahmed \& Masud, 2014; Al-Alak \& Alnaser, 2012). In 2011 Udo, Bagchi, \& Kirs has used modified SERVQUAL instrument by replacing the dimension of Tangibility by Website Content (Udo, Bagchi, \& Kirs, 2008) to reflect the e-learning and online settings in ODL. To find the significant service quality dimensions which would affect Students' Perceived Service Quality and Satisfaction empirically which could be enhanced the ODL environment in OUSL for their students' retention and completion.

\subsection{Research Objectives}

1. To determine the significant factors contributing towards Students' Perceived Service Quality and Satisfaction in ODL in OUSL. 
2. To ascertain the relationship between Students' Perceived Service Quality and Satisfaction in ODL relating to OUSL.

3. To model the significant factors in the final model.

\subsection{Research Questions}

Based on the service quality literature the dimensions of modified SERVQUAL are Assurance, Empathy, Reliability, Responsiveness, and Website Content which could be considered to develop research questions to test the association with student satisfaction in ODL (Mantovani, 2012; Udo, Bagchi, \& Kirs, 2008; Udo, Bagchi, \& Kirs, 2011; Stodnick \& Rogers, January 2008). Research questions of the study are as follows:

1. How does Assurance impacts Students' Perceived Service Quality and Students' Satisfaction in ODL in the OUSL?

2. How does Empathy impacts Students' Perceived Service Quality and Students' Satisfaction in ODL in the OUSL?

3. How does Responsiveness impacts Students' Perceived Service Quality and Students' Satisfaction in ODL in the OUSL?

4. How does Reliability impacts Students' Perceived Service Quality and Students' Satisfaction in ODL in the OUSL?

5. How does Website Content impacts Students' Perceived Service Quality and Students' Satisfaction in ODL in the OUSL?

6. How Students' Perceived Service Quality does impacts Students' Satisfaction in ODL in the OUSL?

\subsection{Significance of the Study}

The results of this study enlighten the path for the academia in ODL in the OUSL. The higher management and policy makers could understand the ranking order of the affective significant factors. They can do the necessary changes conferring to those results in the teaching and learning process to take the strategic decisions to develop the ODL system.

The policy makers can change the policies to enhance the teaching-learning process while implementing the quality assurance process to every program. It is very important in assessing whether every change must link-up with support for the learners from their initial stage to fulfil their requirements and successfully complete their learning journey.

\section{Literature Review}

The service quality concept originated in a marketing environment, but it has gradually moved in to the service industry as well as in the educational environment. Since education is a long-term service it is very important to study the facts connected with service quality and student satisfaction.

\subsection{Service Quality}

In the Service Quality paradigm, it can be find the different types of SQ items and instruments based on the nature of the service and service organisations. The perceived service quality model was constructed under the three dimensions of Functional quality, Technical quality, and Reputational quality of the organisation (Grönroos, 1984). In 1985 Parasuraman, Zeithaml, and Berry (Parasuraman, Zeithaml, \& Berry, 1985) conceptualised a gap model for Service Quality with ten dimensions and subsequently in 1988 they reduced it to a 5 item scale (SERVQUAL) (Parasuraman, 1985) as a scale for measuring consumer perceptions of perceived service quality. It consisted of the dimensions of Assurance, Responsiveness, Empathy, Reliability, and Tangibility. In 1990 Carman has followed generic qualities of the SERVQUAL instrument in three service settings a tyre retailer, a business school and a dental school. With the factor analysis he has identified the underlying dimensions between five to seven. Cronin and Taylor (1992) contradict the framework of SERVQUAL and proposed a 'performance only' new serice quality measurement scale was called SERVPERF. In 1993 Harvey \& Green, 1993 conceptulised the nature of the concept of quality in relation to higher education "Quality can be viewed as exceptional, as perfection, as fitness for purpose, as value for money and as transformative" and it depend on the stakeholder preferences. In 1997 Peterson, Kovel-Jarboe, \& Schwartz have presented a conceptual frame work with key elements which could be practised in higher education and hypothesised between the the quality improvements and the student retention. Managing service quality in higher education (Hill, 1995). In 1997 Athiyaman has presented eight services/service attributes as the determinants of service quality in higher education and conceptualised the basis of consumer satisfaction and perceived quality in the higher education 
sector and their importance. Consequently in the same year by LeBlanc \& Nguyens examined the concept of service quality in business education and identified seven significanr factors which influence student evaluations of service quality. The "descending order of importance of the factors are: reputation, administrative personnel, faculty, curriculum, responsiveness, physical evidence and access to facilities" (LeBlanc \& Nguyen, 1997, p. 72). In 1997 Joseph \& Joseph have examined the determinants of business students' perceptions of service quality in education in New Zealand and revealed the career opportunities, programme issues, cost/time, physical aspects, location, and other were most significant factors relating to service quality. In 2000, Oldfield \& Baron has itentified three dimensions of requisite elements, acceptable elements and functional elements or which are practical in nature. In 2004 Rashid \& Harun has found the the dimensions of serice quality as gender, ethnicity, type of academic programs, and location of learning centers in an ODL institution in Malaysia.The new measurement scale was developed for higher education enviornment called HEdPERF (Higher Education PERFormanceonly) (Abdullah, 2006). The six items in the scale were Non-academic aspects, Academic aspects, Reputation, Access, Program issues, and Understanding. With the development of the information technology a new distinctive process of people-technology interactions has added to the research studies and developed multiple-itemscale (E-S-QUAL) for measuring the service quality delivered by Websites e-service quality (Parasuraman, Zeithaml, \& Malhotra, 2005). In 2006, Prybutok, \& Huang presented e-service quality model which was consisted of individual differences, e-service convenience, Website service quality, risk, e-satisfaction, and intention. They have empirically proved all the constuts were significant except "individual differences" in this measurement scale. The SERVQUAL intrument was applied to the traditional classroom enviornment in a innovative nature by Stodnick \& Rogers, in 2008 for the first time to evaluate students' perceived service quality associated with students' satisfaction with the course, instructor, learning and expected grade. In 2008 Udo, Bagchi, \& Kirs have operationalised web service quality constructs as perceived risk, web content and service convenience. Moreover they have further analysed the relationship with customer satisfaction and behavioral intentions in an e-business environment. In 2011, Udo, Bagchi, and Kirs has empirically presented the modified SERVQUAL constructs by replacing the "Tangibility " dimension with "Website Content" and found significant with four variables except the dimension of Reliability in e-service quality ODL enviornment. Consequently, in 2012, Mantovani has used the same instrument and found the significant dimensions as Assurance, Reliability, and Website Content. In 2012, Çerri has applied the SERVQUAL in Albanian public universities to investigate the service quality consequences and concluded that all five dimensions are significant and the antecedents of service quality.

\subsection{Student Satisfaction}

The definition of Student Satisfaction was specified by Udo, Bagchi,and Kirs,(2011) as "overall assessment of the student learning experience". In 2006 Arambewela \& Hall (Arambewela \& Hall, 2006) has examine the relationship between the SERVQUAL constructs and satisfaction among four cohorts of Asian international postgraduate students studying in Australian universities. In 2008, Hasan, Ilias, Rahman, \& Razak have examined the relationship between SERVQUAL and students satisfaction of bachelors degree students studying at a private HEIs in Malaysia and found that all 5 dimensions were positively significant with student satisfaction. In 2011, Wei and Ramalu have examined the relationship between service quality and student satisfaction in a university of Malaysia by using SERVQUAL instrument and found the significant factors as, Responsiveness, Assurance and Empathy. In 2014 Mansori, Vaz and Ismail used the same indtrument for the private universities and colleges in Malaysia and revealed that Tangibility, Empathy, and Responsiveness were significant with student satisfaction. In 2015, Sembiring has used the SERVQUAL instrument which directly influence the students' satisfaction in ODL perspectives and found the significant relationship with all variables and the students' satisfaction. Assessment of factors which affect Student Satisfaction upon Service Delivery in the newly established universities in Sri Lanka (Wijesiri, 2016). In Zambia, in higher education, service quality performance dimensions (tangibility, reliability, responsiveness, empathy and assurance) are positively significant with overall customer satisfaction (Mwiya, et al., 2017).

\subsection{Service Quality and Students' Satisfaction in ODL}

In 2011 ,Udo, Bagchi and Kirs have proposed a modified SERVQUAL model to evaluate a relationship between e-learning quality in distance education and students' satisfaction and found significant. Followed by the same diemensions, in 2012, Mantovani has empirically proved significant relationship between perceived service quality in distance education and students' satisfaction. Consequently, the studies in higher education institutions disclosed that service quality has a positive significant effect on student's satisfaction (Jiewantoa, Laurens, \& Nellohc, 2012 ; Meštrović, 2017). 


\section{Methodology}

Based on the literature the modified SERVQUAL five (5) dimensions of Assurance, Empathy, Responsiveness, Reliability and Website Content were considered as the independent variables (IV). The dependent variables (DV) for the study were Students' Perceived Service Quality and Satisfaction in ODL in the OUSL. The Instrument was mainly based on literature (Stodnick \& Rogers,2008 ;Udo, Bagchi, \& Kirs ,2008, 2011) and minor modifications were made. The scale of the research instrument except the demographic questions rated with the 5-point Likert scale; 1-Strongly Disagree to 5-Strongly Agree. The Primary data collection method would be a survey based on a self-administered questionnaire consisting of 46 questions which have been validated and tested for reliability in the pilot survey. The six main regional centers in the OUSL were selected and the respondents were 760 undergraduate students who have more than one-year university service experience. The valid responses were only 744 which covered $98 \%$ of the original sample. The Data analysis consists of descriptive and inferential statistics. The Structural Equation Modeling (SEM) was employed by using the 'Partial least square' (PLS) to check the significance of each of the dimensions in the model proposed for evaluating the Students' Perceived Service Quality and Satisfaction. The significant constructs will be used only for model fitting. There are two main statistics model styles known as 'parametric' and 'non-parametric' which implies that a distribution is assumed for the population. An assumption is made when performing a hypothesis test that the data is a sample from a certain distribution; commonly, normal distribution. Non-parametric implies that there is no assumption of the specific distribution of the population which means the non-parametric test results are more robust against the violation of the assumptions (Field, 2011, pp. 264-315; Saunders, Lewis, \& Thornhill, 2011, pp. 449-453).

The following eleven hypotheses were tested.

1. $\mathrm{H}_{1 \mathrm{~A}}$ : There is an association between Assurance and Students' Perceived Service Quality in ODL in OUSL

2. $\mathrm{H}_{2 \mathrm{~A}}$ : There is an association between Assurance and Students' Satisfaction in ODL in OUSL.

3. $\mathrm{H}_{1 \mathrm{~B}}$ : There is an association between Empathy and Students' Perceived Service Quality in ODL in OUSL.

4. $\mathrm{H}_{2 \mathrm{~B}}$ : There is an association between Empathy and Students' Satisfaction in ODL in OUSL.

5. $\mathrm{H}_{1 \mathrm{C}}$ : There is an association between Responsiveness and Students' Perceived Service Quality in ODL in OUSL.

6. $\mathrm{H}_{2 \mathrm{C}}$ : There is an association between Responsiveness and Students' Satisfaction in ODL in OUSL.

7. $\mathrm{H}_{1 \mathrm{D}}$ : There is an association between Reliability and Students' Perceived Service Quality in ODL in OUSL.

8. $\mathrm{H}_{2 \mathrm{D}}$ : There is an association between Reliability and Students' Satisfaction in ODL in OUSL.

9. $\mathrm{H}_{1 \mathrm{E}}$ : There is an association between Website Content and Students' Perceived Service Quality in ODL in OUSL.

10. $\mathrm{H}_{2 \mathrm{E}}$ : There is an association between Website Content and Students' Satisfaction in ODL in OUSL.

11. $\mathrm{H}_{3}$ : There is an association between Students' Perceived Service Quality and Students' Satisfaction in ODL in OUSL. 


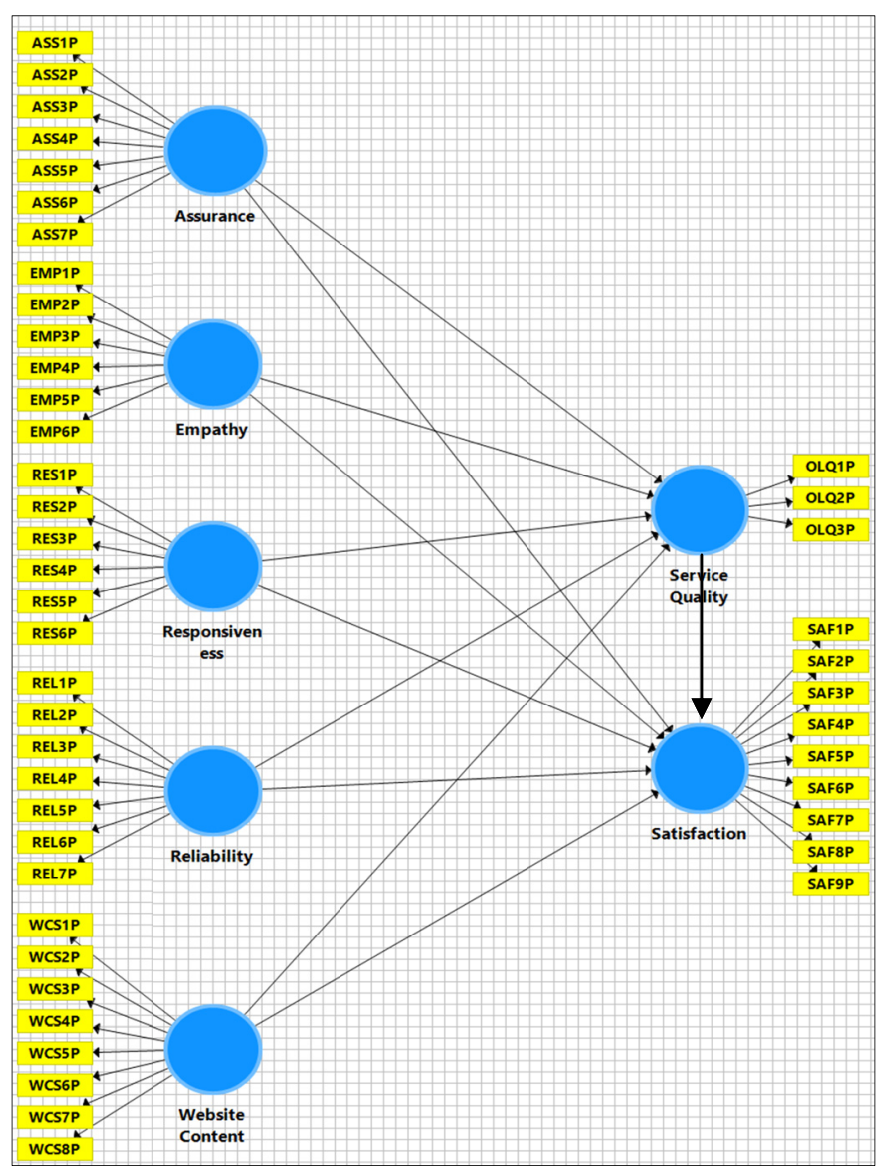

Figure 1. The conceptual Frame work for the study

\subsection{Data Collection}

The research instrument was mainly based on literature (Joseph \& Joseph, 1997; Mantovani, 2012; Stodnick \& Rogers, January 2008; Udo, Bagchi, \& Kirs, 2011) and minor modifications were made. The scale of the research instrument except for the demographic section, other questions were rated using the 5-point Likert scale with 1-Strongly Disagree to 5-Strongly Agree. The Primary data collection method would be a survey with a self-administered questionnaire where 46 questions have been validated and tested for reliability and validity from the pilot survey. The six, main regional centers were selected where the respondents were 760 undergraduate students who have more than one-year university service experience. The valid responses were only 744 which covered $98 \%$ of the original size of the sample.

\subsection{Procedure}

There are two types of SEM, based on variances and covariances. The variance based (SEM) method was employed mainly using the Smart PLS 3.2 software package (Hair, Hult, Ringle, \& Sarstedt, 2017) and Covariance-based SEM (CB-SEM), using software packages such as AMOS, EQS, LISREL and MPlus. Structural Equation Modeling (SEM) is a second-generation multivariate data analysis method mostly used in marketing research which can test theoretically supported linear and additive causal models (Hair, Hult, Ringle, \& Sarstedt, 2017; Wong, 2013). As cited in (Jr, Sarstedt, Hopkins, \& Kuppelwieser, 2014) PLS was originally developed by Wold $(1974,1980,1982)$. The PLS, the SEM technique based on an iterative approach that maximizes the explained variance of endogenous constructs (Fornell \& .Bookstein, 1982).

There are two sub models in PLS. The structural equation model or the inner model which postulates the relationships between the independent and dependent latent (unobserved) variables. The outer model specifies the relationships between the latent variables and their observed indicators. In SEM, there are two types of variables, either exogenous or endogenous. An exogenous variable has path arrows pointing towards the outside only and not leading to it. An endogenous variable has at least one path leading to it and represents the effects of other variable(s) (Hair, Hult, Ringle, \& Sarstedt, 2017; Wong, 2013). 
The test of construct validity was conducted using PLS - it has reduced restrictions on measurement scales, sample size, and residual distributions, compared to the covariance-based SEM. Smart PLS was also used to create the component-based regression/path analysis model. PLS has the advantage of being able to model multiple dependent and independent variables while handling multi-collinearity among the independent variables. It is also robust in handling missing data and the basis of cross-products involving the response variable(s), hence resulting in stronger predictions (Chin, 1998; Hair, Hult, Ringle, \& Sarstedt, 2017).

With SEM, marketers can visually examine the relationships that exists among variables of interest to prioritize resources to better serve their customers. The fact that unobservable, hard-to-measure latent variables can be used in SEM, makes it ideal for tackling business research problems (Jr, Sarstedt, Hopkins, \& Kuppelwieser, 2014). Smart PLS is a partial least square (PLS) based SEM package that has been commonly used in many research programmes; Students' perceived service quality (Twaissi \& Al-Kilani, 2015), student satisfaction and loyalty (Ali, Zhou, Hussain, Nair, \& Ragavan, 2016; Brown \& Mazzarol, 2006; Brown \& Mazzarol, 2009; Ibrahim, Rahman, \& Yasin, 2014), Student satisfaction in ODL (MACHADO-DA-SILVA, MEIRELLES, FILENGA, \& FILHO, July 2014 ), innovations in small and medium-sized enterprises (Boachie-Mensah \& Acquah, 2015), brand quality (Völckner, Sattler, Hennig-Thurau, \& Ringle, 2010 ) value creation (Kumar, 2015), customer satisfaction (Ringle, Sarstedt, \& Zimmermann, 2011), service customization and customer loyalty (Coelho \& Henseler, 2012).

\subsection{Survey Material}

The survey items were mainly based on literature which were validated from the related studies. Minor modifications were made to reflect the ODL environment. The research material consisted of two (2) sections. Section-1 was the demographic data section and the other one consisted of 46 questions which were rated using the 5-point Likert scale, with 1-Strongly Disagree to 5-Strongly Agree (Appendix O consists of Section-2). The survey instrument was mainly developed to collect data and to test the hypotheses based on the proposed conceptual frame work.

\subsubsection{Assurance, Empathy, Responsiveness, and Reliability}

These four constructs were mainly based on the original SERVQUAL (Parasuraman, Zeithaml, \& Berry., 1988) instrument. For the first time in 2008 Stodnick \& Rogers (Stodnick \& Rogers, January 2008) have applied this instrument in the classroom enviornment. Later in USA by Udo, Bagchi, \& Kirs(2011) and Mantovani (2012) used same variables for the distance education e-learning enviornment in Brazil. There were 26 questions in section-2 based on these four(4) constructs. The Assurance in ODL in the OUSL mainly focused on knowledge and courtesy of the staff and has seven(7) items. The Empathy in ODL in the OUSL assessed the individualised caring and attention and consisted with 6 (six) items. The responsiveness in ODL in the OUSL evaluated as the willingnes to help the the students and make available a prompt service and measured from six (6) items. The construct of Reliability in ODL in the OUSL guaged through the reliable promised service consistently and accurately from seven(7) items (Udo, Bagchi, \& Kirs, 2011).

\subsubsection{Website Content}

The eight (8) items for this construct were taken from (Udo, Bagchi, \& Kirs, 2011) and validated from the pilot survey. The questions are intended to measure the usefulness, quality, relevancy of the intended information and how multimedia features integrated to the website; the efficient way of applying the audio, video graphics and animation for on-line lessons.

\subsubsection{Perceived Service Quality (PSQ)}

Perceived service quality is described in terms of the "customer's assessment of the overall excellence or superiority of the service" (Mantovani, 2012; Zeithaml, 1988). Measures of Perceived Service Quality have been developed in previous studies (Mantovani, 2012; Udo, Bagchi, \& Kirs, 2011). There were three items which reflect overall perceptions of quality, course content and superiority of the service when compared with other institutions.

\subsubsection{Students' Satisfaction (SAT)}

Students' Satisfaction is defined as "extent to which the students feels the service provided fulfils his/her expectations" (Mantovani, 2012; Udo, Bagchi, \& Kirs, 2011), "Overall satisfaction with distance learning experience" (Sahin \& Shelley, 2008; Strachota, 2006). This construct measures the overall assessment of the students learning experience, pleasure and how satisfied are they with the service offered by the University. There were nine (9) items included based on the literature (Gruber, Fuß, Voss, \& Glaeser-Zikuda, 2010; Mantovani, 2012; Udo, Bagchi, \& Kirs, 2011; Völckner, Sattler, Hennig-Thurau, \& Ringle, 2010 ; Yang \& 
Peterson, 2004).

\section{Data Analysis and Results}

PLS-SEM results are evaluated using a systematic process. The main purpose of this method is to maximise the explained variance $\left(\mathrm{R}^{2}\right)$ of the endogenous latent variables in the PLS path model. As a result, the evaluation quality of the PLS-SEM measurement and structural models focuses on the predictive capabilities of the models. The systematic evaluation of these criteria follows a separate assessment of a two-step process of the measurement model and structural model. The structural model will be evaluated after establishing the reliability and validity of the constructs. There are two types of measurement model specifications: Reflective and Formative measurement models (Hair, Hult, Ringle, \& Sarstedt, 2017).

In the reflective model, the relationship (causality) goes from the construct to its measures. Reflective indicators could be viewed as a representative sample of all the possible items available within the conceptual domain of the construct. All indicator items are caused by the same construct and should be highly correlated with each other. The construct must have sufficient reliability, even the single item exchange or drop (Hair, Hult, Ringle, \& Sarstedt, 2017). In formative measurement model, the construct forms the causal indicators. The most important feature of this model is the formative indicators cannot be interchangeable. The omitting of an indicator potentially alters the nature of the construct (Hair, Hult, Ringle, \& Sarstedt, 2017). For the current study, the conceptual model consists of the reflective measurement model which has the relationships from construct to the indicators.

\subsection{Measurement Model Analysis}

An evaluation of the measurement model consists of Internal Consistency (Cronbach's Alpha), Composite Reliability (CR)), Convergent Validity (individual Indicator Reliability and Average Variance Extracted) and the Discriminant Validity (Cross-Loadings, Fonell-Larcker criterion, Heterotrait-Monotrait (HTMT) values) (Hair, Hult, Ringle, \& Sarstedt, 2017). The results of the outer loadings of the reflective constructs (Appendix A) shows some items are having less than 0.7. As a rule of thumb, the outer loadings should be at least 0.7 or more. The Indicator Reliability which is the square value of Outer Loadings of the items, and which is giving the minimum value as 0.50 that will cover the $50 \%$ of the value as the variance extracted from the item (Hair, Hult, Ringle, \& Sarstedt, 2017). The indicators which indicated the poor Indicator Reliability $(<0.50)$ or Outer loadings $(<0.7)$ were dropped. The dropped indicators were $(\mathrm{ASS} 7 \mathrm{P}=0.655$, EMP5P $=0.660$, EMP6P $=0.668$, REL5P $=0.684$, REL6P $=0.620$, REL7P=0.688, RES6P $=0.625, \mathrm{SAF} 8 \mathrm{P}=0.669$, SAF9P $=0.666$ ).

As a rule of thumb, the Cronbach's Alpha and Composite Reliability values must be greater than 0.7 and the AVE must be higher than 0.50. The results of Cronbach's Alpha (CR), Composite Reliability and Average Variance Extracted (AVE) have reached up to the required standard (Appendix B) ( (Hair, Hult, Ringle, \& Sarstedt, 2017).

The assessment of the discriminant validity the Fonell-Larcker criterion, the square root of the AVE of each construct should be greater than the constructs' highest correlation with any other construct in the model. The results of the Fonell-Larcker criterion (Appendix D) presented the square root of the reflective constructs' AVE on the diagonal values are greater than any value of the correlation between the constructs in the off diagonal raw and column position. Another discriminant method is Cross Loadings of the indicators loadings. All loadings on its assigned construct must be higher than all other cross loadings of the other constructs. The results showed (Appendix C) all loadings with the assigned constructs have reached the highest correlation with their own indicators. The third method of the discriminant validity is the Heterotrait-Monotrait (HTMT) values. The bootstrap (5000 samples) confidence intervals values should be significantly different from one (1). The columns labelled $2.5 \%$ and $97.5 \%$ show the lower and upper boundary of the $95 \%$ bias corrected confidence interval. As the results showed (Appendix E) neither of the lower or upper boundary confidence intervals are included in the value of 1 (Hair, Hult, Ringle, \& Sarstedt, 2017; Henseler, Ringle, \& Sarstedt, 2015).

\subsection{Structural Model Fit Analysis}

After analysing the measurement model, the structural model will be assessed. As a first step collinearity must be accessed. The critical levels of the Tolerance values are less than 2 and the Variance Inflation Factor (VIF) are less than 5 to avoid the multicollinearity problems. The values of the VIF values in the (Appendix F) and all values are less than or equal 2 and can be confirmed there is no issues of multicollinearity problems (Hair, Hult, Ringle, \& Sarstedt, 2017). The key criteria for assessing the structural model in PLS-SEM are the significance of the path coefficients. The $1^{\text {st }}$ step of the structural model path coefficients were checked against the rule of thumb from 5000 samples of bootstrap $t$ values and the $p$ values. The critical $t$ values for two tailed tests are 1.65 
(significance level 10\%), 1.96 (significance level 5\%) and 2.57 (significance level 1\%). When p values are considered, if the significance level is $5 \%$, the $\mathrm{p}$ values must be smaller than 0.05 to consider the relationship as a significant at 5\% level. The significant relationships are revealed between SPSQ and Reliability, SPSQ and Responsiveness, SPSQ and Website Content. And consequently, the Students SAT and Reliability and Students SAT and Website Content. And the Students' Perceived Service Quality and Students' Satisfaction (Appendix I). The non-significant relationships were deleted from the model and final model was generated again with the 5000 samples of bootstrap method (Hair, Hult, Ringle, \& Sarstedt, 2017). The Fig. 2 shows final model of the study with only significant relationships and significant outer loadings of each construct (Hair, Hult, Ringle, \& Sarstedt, 2017).

The most common method of evaluating the structural model is the coefficient of determination $\left(\mathrm{R}^{2}\right.$ value) which is used to measure the predictive power of the model. This value represents the exogenous latent variable's combined effects on the endogenous latent variable. That is the amount of variance in the endogenous constructs explained by all of the exogenous constructs linked to it (Hair, Hult, Ringle, \& Sarstedt, 2017). The $\mathrm{R}^{2}$ for the Students' Perceived Service Quality is $0.244(24 \%)$ and can be considered as rather weak and Students Satisfaction is $0.549(55 \%)$ can be considered as moderate (Appendix J).

The SRMR is the square root of the sum of the squared differences between the model-implied and the empirical correlation matrix (Henseler, Hubona, \& Ray, 2016). A value of 0 for SRMR would indicate a perfect fit, but models can yield SRMR values of 0.064 and higher (Henseler, et al., 2014). Therefore, a cut-off value of less than 0.08 as proposed by (Hu \& Bentler, 1999). For this model the SRMR is 0.064 and considered as a good fit.

The RMS theta builds on the outer model residuals, which are the differences between predicted indicator values and the observed indicator values. $\mathrm{RMS}_{\text {theta }}$ values below 0.12 indicate a well-fitting model, whereas higher values indicate a lack of fit (Henseler, et al., 2014). For this model $\mathrm{RMS}_{\text {theta }}$ is 0.117 and considered as good fit (Hair, Hult, Ringle, \& Sarstedt, 2017).

\section{The Results}

The valid number of responses were 744 out of 760 with a rating of $98 \%$ from the sample size of 760 . Most of the respondents were male representing $481(64.7 \%)$ and $263(35.3 \%)$ were female. $1.1 \%(8)$ of the Respondents were of an age less than $20 ; 75.4 \%$ (561) were between the ages $20-25 ; 17.7 \%$ (132) were between the ages $26-30$; $4.8 \%$ (36) were between the ages 31-40, and 0.9\% (7) were between the ages 41-50. The Regional Centre based representation of respondents were, Colombo 426 (56\%), Kandy 153 (20\%), Matara 75 (10\%), Anuradhapura 30 (4\%), Jaffna 30 (4\%), and Batticoloa $30(4 \%)$.

The summary of the finalised measurement model is depicted in Table 1. All the significant constructs included in the final model are tabulated with their Outer Loadings, Indicator Reliability, AVE (Appendix K), Composite Reliability (Appendix L), Cronbach's Alpha (Appendix M) and HTMT (Appendix N) values. All the constructs have indicated strong reliability and validity values.

Table 1 . The results summary of the final measurement model

\begin{tabular}{|c|c|c|c|c|c|c|c|}
\hline \multirow[t]{2}{*}{ Latent Variable } & \multirow[t]{2}{*}{ Indicators } & \multicolumn{3}{|c|}{ Convergent Reliability } & \multirow{2}{*}{$\begin{array}{l}\text { Internal } \\
\text { Reliability } \\
\text { Composite } \\
\text { Reliability } \\
0.60-0.90 \\
\end{array}$} & \multirow{2}{*}{$\begin{array}{l}\text { Consistency } \\
\text { Cronbach's } \\
\text { Alpha } \\
0.60-0.90 \\
\end{array}$} & \multirow{2}{*}{$\begin{array}{l}\text { Discriminant } \\
\text { Validity } \\
\text { HTMT confidence } \\
\text { Interval does not } \\
\text { include } 1\end{array}$} \\
\hline & & $\begin{array}{l}\text { Outer } \\
\text { Loadings }>0.70\end{array}$ & $\begin{array}{l}\text { Indicator } \\
\text { Reliability }>0.50\end{array}$ & $\mathrm{AVE}>0.50$ & & & \\
\hline \multirow[t]{3}{*}{ Service Quality } & OLQ1P & 0.862 & 0.744 & & & & \\
\hline & OLQ2P & 0.879 & 0.773 & 0.726 & 0.888 & 0.812 & YES \\
\hline & OLQ3P & 0.814 & 0.663 & & & & \\
\hline \multirow[t]{4}{*}{ Reliability } & REL1P & 0.849 & 0.721 & \multirow{4}{*}{0.636} & \multirow{4}{*}{0.874} & \multirow{4}{*}{0.809} & \multirow{4}{*}{ YES } \\
\hline & REL2P & 0.770 & 0.593 & & & & \\
\hline & REL3P & 0.826 & 0.682 & & & & \\
\hline & REL4P & 0.740 & 0.547 & & & & \\
\hline \multirow[t]{5}{*}{ Responsiveness } & RES1P & 0.843 & 0.711 & & & & \\
\hline & RES2P & 0.811 & 0.658 & & & & \\
\hline & RES3P & 0.819 & 0.671 & 0.642 & 0.900 & 0.862 & YES \\
\hline & RES4P & 0.766 & 0.587 & & & & \\
\hline & RES5P & 0.764 & 0.583 & & & & \\
\hline
\end{tabular}




\begin{tabular}{|c|c|c|c|c|c|c|c|}
\hline \multirow[t]{7}{*}{ Satisfaction } & SAF1P & 0.794 & 0.631 & \multirow{7}{*}{0.568} & \multirow{7}{*}{0.902} & \multirow{7}{*}{0.873} & \multirow{7}{*}{ YES } \\
\hline & SAF2P & 0.741 & 0.549 & & & & \\
\hline & SAF3P & 0.761 & 0.580 & & & & \\
\hline & SAF4P & 0.736 & 0.542 & & & & \\
\hline & SAF5P & 0.776 & 0.602 & & & & \\
\hline & SAF6P & 0.737 & 0.544 & & & & \\
\hline & SAF7P & 0.728 & 0.531 & & & & \\
\hline Website & WCS1P & 0.788 & 0.621 & \multirow{8}{*}{0.612} & \multirow{8}{*}{0.927} & \multirow{8}{*}{0.910} & \multirow{8}{*}{ YES } \\
\hline \multirow[t]{7}{*}{ Content } & WCS2P & 0.796 & 0.634 & & & & \\
\hline & WCS3P & 0.806 & 0.650 & & & & \\
\hline & WCS4P & 0.735 & 0.540 & & & & \\
\hline & WCS5P & 0.789 & 0.623 & & & & \\
\hline & WCS6P & 0.795 & 0.632 & & & & \\
\hline & WCS7P & 0.763 & 0.583 & & & & \\
\hline & WCS8P & 0.785 & 0.616 & & & & \\
\hline
\end{tabular}

The Collinearity Statistics (VIF) of the constructs in the final model are distinctly below the threshold value of 5 . Therefore, no collinearity issues of the predictor variables in the structural model (Appendix H). The $\mathrm{R}^{2}$ value for the endogenous variables of Students' Perceived Service Quality is 0.244 and Students' Satisfaction is 0.549 and can be considered as weak and moderate respectively as compared with the threshold values. All the constructs in the finalised structural model are significant and the path coefficients and significance levels are shown in Fig. 2. Values are given in (Appendix I). The order of the relative importance of the significant drivers of the Students' Perceived Service Quality is; Website Content (0.323), Reliability (0.214) and Responsiveness (0.079). The ranking order for the significant exogenous variables of Students' Satisfaction are Website Content (0.415) and Reliability (0.323). There is a significant relationship between the Students' Perceived Service Quality and the Students' Satisfaction (0.224). The summary of the hypotheses are tabulated in Table 2.

Table 2. The summary of the hypotheses (Appendix G and Appendix I)

\begin{tabular}{|c|c|c|}
\hline Hypothesis & $\begin{array}{l}\text { Path Coefficient } \\
\text { (significance Value) }\end{array}$ & $\begin{array}{l}\text { Support } \\
(\mathrm{Y} / \mathrm{N})\end{array}$ \\
\hline $\begin{array}{l}\text { 1. } \mathrm{H}_{1 \mathrm{~A}} \text { : There is an association between Assurance and Students' Perceived Service Quality } \\
\text { in ODL in SL }\end{array}$ & $0.031(0.502)$ & No \\
\hline 2. $\mathrm{H}_{2 \mathrm{~A}}$ : There is an association between Assurance and Students' Satisfaction in ODL in SL. & $0.049(0.081)$ & No \\
\hline $\begin{array}{l}\text { 3. } \mathrm{H}_{1 \mathrm{~B}} \text { : There is an association between Empathy and Students' Perceived Service Quality } \\
\text { in ODL in SL. }\end{array}$ & $0.018(0.706)$ & No \\
\hline 4. $\mathrm{H}_{2 \mathrm{~B}}$ : There is an association between Empathy and Students' Satisfaction in ODL in SL. & $0.049(0.182)$ & No \\
\hline $\begin{array}{l}\text { 5. } \mathrm{H}_{1 \mathrm{C}} \text { : There is an association between Responsiveness and Students' Perceived Service } \\
\text { Quality in ODL in SL. }\end{array}$ & $0.079(0.026)$ & Yes \\
\hline $\begin{array}{l}\text { 6. } \mathrm{H}_{2 \mathrm{C}} \text { : There is an association between Responsiveness and Student's Satisfaction in ODL } \\
\text { in SL. }\end{array}$ & $0.027(0.494)$ & No \\
\hline $\begin{array}{l}\text { 7. } \mathrm{H}_{1 \mathrm{D}} \text { : There is an association between Reliability and Students' Perceived Service Quality } \\
\text { in ODL in SL. }\end{array}$ & $0.301(0.000)$ & Yes \\
\hline 8. $\mathrm{H}_{2 \mathrm{D}}$ : There is an association between Reliability and Students' Satisfaction in ODL in SL. & $0.214(0.000)$ & Yes \\
\hline $\begin{array}{l}\text { 9. } \mathrm{H}_{1 \mathrm{E}} \text { : There is an association between Website Content and Students' Perceived Service } \\
\text { Quality in ODL in SL. }\end{array}$ & $0.323(0.000)$ & Yes \\
\hline $\begin{array}{l}\text { 10. } \mathrm{H}_{2 \mathrm{E}} \text { : There is an association between Website Content and Students' Satisfaction in ODL } \\
\text { in SL. }\end{array}$ & $0.415(0.000)$ & Yes \\
\hline $\begin{array}{l}\text { 11. } \mathrm{H}_{3} \text { : There is an association between Students' Perceived Service Quality and Students' } \\
\text { Satisfaction in ODL in SL. }\end{array}$ & $0.224(0.000)$ & Yes \\
\hline
\end{tabular}




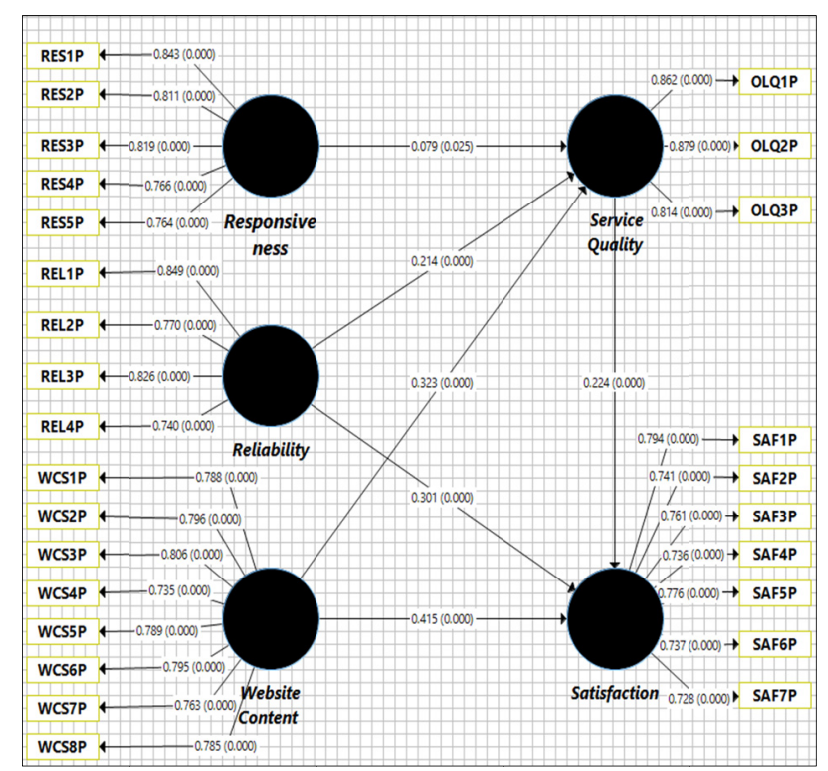

Figure 2. Path coefficients and the significant values for the final model of the study

\section{Discussion and Conclusion}

The objectives of the study were established. The results and the final model as depicted in (Fig. 2). The summary of the hypotheses in Table 2 shows the final output results of the conceptual model in (Fig.1) The construct of Website Content has the strongest relationship with the dependent variables of Service Quality and Satisfaction. The results are consistent with the study of (Mantovani, 2012; Udo, Bagchi, \& Kirs,2011). The Reliability and Responsiveness is significant with the Students Perceived Service Quality. The dimensions of Reliability and Website Content are only significant with the Students Satisfaction and the results are consistent with the study of (Mantovani, 2012; Udo, Bagchi, \& Kirs, 2011). The final results of the dimension of Reliability is significant with the PSQ and consistent with Mantovani (2012 ) and inconsistent with the study of Udo, Bagchi, \& Kirs(2011). The significant results of Responsiveness with the PSQ is consistent with Udo, Bagchi, \& Kirs(2011) and inconsistent with the study of Mantovani (2012). The insignificant results of the dimension of Assurance with the PSQ is inconsistent with the studies of (Ahmed \& Masud, 2014; Mantovani, 2012; Udo, Bagchi, \& Kirs, 2011). The insignificant results of the dimension of Empathy with the PSQ is consistent with the study of Mantovani.(2012) and contradictory with the study of (Udo, Bagchi, \& Kirs, 2011). The significant results of the dimension of Reliability with the SAT is consistent with the studies of (Al-Alak \& Alnaser, 2012; Mwiya, et al., 2017; Sembiring, 2015 ) and inconsistent with (Mansori, Vaz, \& Ismail, 2014; Wei \& Ramalu, 2011).The insignificant results of the dimension of Assurance with the SAT is inconsistent with the study of Ahmed \& Masud (2014) and consistent with that of Sembiring (2015). The insignificant results of the dimension of Empathy with the SAT is inconsistent with the study of Ahmed \& Masud (2014) and Sembiring (2015). The insignificant results of the dimension of Responsiveness with the SAT is inconsistent with the study of Mwiya, et al. (2017).

The insignificant relations that students have granted the qualities of Asurance and Empathy of their teaching staff. The other three (Responsiveness, Reliability,Website Content) service qualities must taken in to consideration and must pay much attention to enhace the service quality of the offered service with these significant factors. The dimensions of Reliability and Website Content are the only two significant factors with the SSAT. The other three; Assurance, Empathy and Responsiveness are not significant with Students' Satisfaction. These results have revealed that the promised service must be offerered reliably with a higher level of quality and Website Quality must be maintained with audio, video, and with useful contents focused on the courses.

The variance extracted $\left(\mathrm{R}^{2}\right)$ for Service Quality is $0.244(24.4 \%)$ and Satisfaction is $0.549(55 \%)$. This study considered only the students' perspectives. This limitation can be recovered from a future research in selecting more service quality variables from stakeholders and institutional perspectives. Further, it is more comprehensive if longitudinal studies are carried out in regional centers to understand more about student attitudes by means of improving the other limitation of cross sectional study. "As a concept, the construct of Quality is relative and evolving. in higher education, quality is a construct relative to the unique perspectives and interpretations of different stakeholder groups - students, alumni, faculty, administrators, parents, oversight 
boards, employers, state legislature, local governing bodies, accrediting associations, transfer institutions, and the general public" (Mbwesa, 2014, p. 86). The delivery of a quality service continually is very difficult but it can be risen the organisational revenues (Zeithaml, 1988). As a future research the relation between student retention and attrition based on the revenu of the institution can be studied.

\section{References}

Abdullah, F. (2006). The development of HEdPERF: a new measuring instrument of service quality for the higher education sector. International Journal of Consumer Studies, 30(6), 569-581. https://doi.org/10.1111/j.1470-6431.2005.00480.x

Ahmed, S., \& Masud, M. M. (2014). Measuring Service Quality of a Higher Educational Institute towards Student Satisfaction. American Journal of Educational Research, 2(7), 447-455. https://doi.org/10.12691/education-2-7-3

Al-Alak, B. A., \& Alnaser, A. S. (2012). Assessing the Relationship Between Higher Education Service Quality Dimensions and Student Satisfaction. Australian Journal of Basic and Applied Sciences, 6(1), 156-164. Retrieved from http://ajbasweb.com/old/ajbas/2012/January/156-164.pdf

Ali, F., Zhou, Y., Hussain, K., Nair, P. K., \& Ragavan, N. A. (2016). Does higher education service quality effect student satisfaction, image and loyalty?. Quality Assurance in Education, 24(1), 70-94. https://doi.org/10.1108/QAE-02-2014-0008

Arambewela, R., \& Hall, J. (2006). A Comparative Analysis Of International Education Satisfaction Using Servqual. Journal of Services Research, 6(Special Issue (July)), 141-163.

Ariyaratne, A., Munasinghe, D. M., Seneviratne, P., Rajapaksha, P. L., \& Dediwala, D. D. (2014). A study on non-completing students of the Certificate in Pre-school Education programme at the Open University of Sri Lanka. 28th Annual Conference of the Asian Association of Open Universities (AAOU 2014) 28-31 October 2014 (pp. 126-134). The Open University of Hong Kong s Hong Kong SAR, China.

Athiyaman, A. (1997). Linking student satisfaction and service quality perceptions: the case of university education. European Journal of Marketing, 31(7), 528-540. Retrieved from http://dx.doi.org/10.1108/03090569710176655

Boachie-Mensah, F., \& Acquah, I. S. (2015). The Effect of Innovation Types on the Performance of Small and Medium Sized enterprises in the Sekondi:Takoradi Metropolis. Archives'of'Business'Research,, 3(3), 77-98. https://doi.org/10.14738/abr.33.1240

Brown, R. M., \& Mazzarol, T. W. (2006). Factors Driving Student Satisfaction and Loyalty in Australian Universities: The Importance of Institutional Image. Paper presented at the 20th Annual Australia \& New Zeland Academy of Management (ANZAM) Conference 2006, Rockhampton. 6-10 December 1. Retrieved from http://www.cemi.com.au/sites/all/publications/ANZAM\%20BROWNMAZZ06.pdf

Brown, R. M., \& Mazzarol, T. W. (2009). The importance of institutional image to student satisfaction and loyalty within higher education. High Educ , 58, 81-95. https://doi.org/10.1007/s10734-008-9183-8

Carman, J. (1990). Consumer perceptions of service quality: an assessment of the SERVQUAL dimensions. Journal of Retailing, 66(1), 33-55.

Çerri, S. (2012). ASSESSING THE QUALITY OF HIGHER EDUCATION SERVICES USING A MODIFIED SERVQUAL SCALE. Annales Universitatis Apulensis Series Oeconomica, 14(2), 664-679.

Chakuchichi, D. (2011). Student Retention as a Function of the Quality of Learner Support in Open and Distance Learning: Students' Perceptions at the Zimbabwe Open University. Zimbabwe International Journal of Open \& Distance Learning , l(1), 90-98. Retrieved 04 16, 2015, from http://www.lis.zou.ac.zw:8080/dspace/bitstream/0/95/1/student\%20retention.pdf

Chin, W. W. (1998). The partial least squares approach to structural equation modeling. In G. A. Marcoulides (Ed.), Modern methods for business research (pp. 295-336). Lawrence Erlbaum Associates, Mahawah , New Jersey,London. Retrieved from https://www.researchgate.net/profile/Wynne_Chin/publication/232569511_The_Partial_Least_Squares_Ap proach_to_Structural_Equation_Modeling/links/0deec533e0f7c00f59000000/The-Partial-Least-Squares-Ap proach-to-Structural-Equation-Modeling.pdf

Coelho, P. S., \& Henseler, J. (2012). Creating customer loyalty through service customization. European Journal of Marketing, 46(3/4), 331-356. https://doi.org/10.1108/03090561211202503 
Cronin, J. J., \& Taylor, S. A. (1992, july). Measuring Service Quality: A Reexamination and Extension. Journal of Marketing, 56(3), 55-68.

De Zoysa, T. S., Munasinghe, D. M., Seneviratne, P., \& Mukunthan, T. (2011). Study On Student Dropout In Advanced Certificate In Pre School Education Programme In The Open University Of Sri Lanka. Annual Academic Session. Open University of Sri Lanka.

Field, A. (2011). Discovering Statistics Using SPSS (and sex and drugs and rock ' $n$ ' roll) Third Edition. SAGE.

Fornell, C., \&.Bookstein, F. D. (1982, November). Two Structural Equation Models : LISREL and PLS Applied to Consumer Exit-Voice Theory. Journal of Marketing Research, 19, 440-452.

Grönroos, C. (1984). A Service Quality Model and its Marketing Implications. European Journal of Marketing, 18( 4), 36 - 44. http://dx.doi.org/10.1108/EUM0000000004784

Gruber, T., Fuß, S., Voss, R., \& Glaeser-Zikuda, M. (2010). Examining Student Satisfaction with Higher Education Services Using a New Measurement Tool. International Journal of Public Sector Management, 23(2), 105 - 123. http://dx.doi.org/10.1108/09513551011022474

Hair, J. F., Hult, G. T., Ringle, C. M., \& Sarstedt, M. (2017). A Primer on Partial Least Squares Structural Equation Modeling (PLS-SEM) (second Edition).

Harvey, L., \& Green, D. (1993 , January ). 'DEFINING' QUALITY for Assessment and Evaluation in Higher Education. An International Journal.

Hasan, H. F., Ilias, A., Rahman, R. A., \& Razak, M. Z. (2008, July). Service Quality and Student Satisfaction: A Case Study at Private Higher Education Institutions. International Business Research, 1(3), 163-175. Retrieved from www.ccsenet.org/journal.html

Henseler, J., Dijkstra, T. K., Sarstedt, M., Ringle, C. M., Diamantopoulos, A., Straub, D. W.,... Calantone, R. J. (2014). Common Beliefs and Reality About PLS: Comments on Ro“nkko“ and Evermann (2013). Organizational Research Methods, 17(2), 182-209. https://doi.org/10.1177/1094428114526928

Henseler, J., Hubona, G., \& Ray, P. A. (2016). Using PLS path modeling in new technology research: updated guidelines. Industrial Management \& Data Systems, $116(1), \quad 2-20$. https://doi.org/10.1108/IMDS-09-2015-0382

Henseler, J., Ringle, C., \& Sarstedt, M. (2015, January). A new criterion for assessing discriminant validity in variance-based structural equation modeling. Journal of the Academy of Marketing Science, 43(1), 115-135. Retrieved from http://link.springer.com/article/10.1007/s11747-014-0403-8

Hill, F. M. (1995). Managing service quality in higher education. Quality Assurance in Education, 3(3), 10-21.

Hu, L.-t., \& Bentler, P. M. (1999). Cutoff criteria for fit indexes in covariance structure analysis: Conventional criteria versus new alternatives. Structural Equation Modeling: A Multidisciplinary Journal, 6(1), 1-55. https://doi.org/10.1080/10705519909540118

Ibrahim, M. Z., Rahman, M. N., \& Yasin, R. M. (2014). Determining Factors of Students' Satisfaction with Malaysian Skills Training Institutes. International Education Studies, $7(6)$. https://doi.org/10.5539/ies.v7n6p9

Ismail, A. G. (1997 August). A critical study on factors influencing the student dropout from the educational programmes offered by the Open University of Sri Lanka(Doctoral Thesis). Faculty of Education ,University of Colombo,Sri Lanka.

Jiewantoa, A., Laurens, C., \& Nellohc, L. (2012 ). International Conference on Asia Pacific Business Innovation and Technology Management Influence of Service Quality, University Image, and Student Satisfaction toward WOM Intention: A Case Study on Universitas Pelita Harapan Surabaya. Procedia-Social and Behavioral Sciences , 40, 16-23. https://doi.org/10.1016/j.sbspro.2012.03.155

Jones, D. (2009). student retention- Helping students to succeed. Retrieved from http://www.ncl.ac.uk/ltds/assets/documents/DawnJones.pdf

Jones, S., Berry, C., Gregson, J., \& Smith, P. (2008). Improving Student Retention in Postgraduate Distance Education at The University of London. Improving Student Retention in Postgraduate Distance Education at the University of London Final Report. Retrieved from https://cdelondon.files.wordpress.com/2011/01/tra3jones-final-report-_cde-format_.pdf 
Joseph, M., \& Joseph, B. (1997). Service quality in education: a student perspective. Quality Assurance in Education, 5(1), 15-21. http://dx.doi.org/10.1108/09684889710156549

Jr, J. F., Sarstedt, M., Hopkins, L., \& Kuppelwieser, V. G. (2014). Partial least squares structural equation modeling (PLS-SEM) An emerging tool in business research. European Business Review, 26(2), 106-121. https://doi.org/10.1108/EBR-10-2013-0128

Jurkowitsch, S., Vignali, C., \& Kaufmann, H.-R. (2006 ). A Student Satisfaction Model For Austrian Higher Education Providers Considering Aspects Of Marketing Communications. Innovative Marketing, 2(3), 9-23.

Kumar, B. R. (2015). Determinants of Value Creation of GCC Firms - An Application of PLS SEM Model. Asian Journal of Finance and Accounting, 7(1), 76-95.

LeBlanc, G., \& Nguyen, N. (1997). Searching for excellence in business education: an exploratory study of customer impressions of service quality. International Journal of Educational Management, 11(2), 72-79. doi:10.1108/09513549710163961

Liyanagama, J. (2014). Factors affecting the drop-out rate on the Engineering degree programme at the Open University of Sri Lanka. In K. C. Danny Wong, \& K. S. Yuen (Ed.), 28th Annual Conference Asian Association of Open Universities 28-31 October 2014 (pp. 259-270). Hong Kong SAR, China: The Open University of Hong Kong. Retrieved from http://library.wou.edu.my/proceedings/AAOU_Proceedings28th.pdf

Machado-Da-Silva, F. N., Meirelles, F. D., Filenga, D., \& Filho, M. B. (July 2014 ). Student Satisfaction Process In Virtual Learning System: Considerations Based In Information And Service Quality from Brazil's Experience. Turkish Online Journal of Distance Education-TOJDE, 15(3) 122-142. Retrieved from http://tojde.anadolu.edu.tr/yonetim/icerik/makaleler/988-published.pdf

Mansori, S., Vaz, A., \& Ismail, Z. M. (2014, March ). Service Quality, Satisfaction and Student Loyalty in Malaysian Private Education. Asian Social Science, 10(7), 57-66.

Mantovani, D. M. (2012). Distance Education on the Stakeholders Perspectives :Student's ,Instructor's and Administrator's Perspectives(Doctoral dissertation). Retrieved 10 29, 2014, from www.teses.usp.br/teses/disponiveis/12/...07112012.../DaiellyMelinaNassifMantovani.pdf

Mbwesa, J. K. ( 2014, April). Transactional Distance as a Predictor of Perceived Learner Satisfaction in Distance Learning courses :A case study of Bachelor of Education Arts Program, University of Nairobi ,Kenya. Journal of Education and Training Studies, 2(2). https://doi.org/10.11114/jets.v2i2.291

Meštrović, D. (2017). SERVICE QUALITY, STUDENTS' SATISFACTION AND BEHAVIOURAL INTENTIONS IN STEM AND IC HIGHER EDUCATION INSTITUTIONS. Interdisciplinary Description of Complex Systems , 15(1), 66-77. https://doi.org/10.7906/indecs.15.1.5

Mwiya, B., Bwalya, J., Siachinji, B., Sikombe, S., Chanda, H., \& Chawala, M. (2017). Higher Education Quality and Student Satisfaction Nexus: Evidence from Zambia. Creative Education, 8, 1044-1068. https://doi.org/10.4236/ce.2017.87076

Oldfield, B. M., \& Baron, S. (2000). Student perceptions of service quality in a UK university business and management faculty. Quality Assurance in Education, 8(2), 85-95. Retrieved from http://dx.doi.org/10.1108/09684880010325600

Open and Distance Learning - Key Terms \& Definitions Commonwealth of Learning CC BY SA. (June 2015). Commonwealth of Learning CC BY SA.

Parasuraman, A., Zeithaml, V. A., \& Berry, L. L. (1985). A Conceptual Model of Service Quality and Its Implications for Future Research. The Journal of Marketing, 49(4), 41-50. Retrieved from http://www.jstor.org/stable/1251430

Parasuraman, A., Zeithaml, V. A., \& Berry., L. L. (1988). SERVQUAL: A Multiple-Item Scale for Measuring Consumer Perceptions of Service Quality. Journal of Retailing, 64(1), 12-40.

Parasuraman, A., Zeithaml, V. A., \& Malhotra, A. (2005). E-S-QUAL A Multiple-Item Scale for Assessing Electronic Service Quality. Journal of Service Research, 7(10), 1-21. https://doi.org/10.1177/1094670504271156 
Peterson, S. L., Kovel-Jarboe, P., \& Schwartz, S. A. (1997). Quality Improvement in Higher Education: implications for student retention. Quality in Higher Education, 3(2), 131-141. https://doi.org/10.1080/1353832970030204

Rashid, M. Z., \& Harun, H. (2004). Service Quality in the Open and Distance Learning-The Perspective of Learners in Malaysia. Retrieved 02 05, from http://eprints.oum.edu.my/71/1/Service_quality_in_the_open_and_distance_learning.pdf

Ringle, C. M., Sarstedt, M., \& Zimmermann, L. (2011). Customer Satisfaction with Commercial Airlines: The Role of Perceived Safety and Purpose of Travel. Journal of Marketing Theory and Practice, 19(4), 459-472. Retrieved from http://dx.doi.org/10.2753/MTP1069-6679190407

Sahin, I., \& Shelley, M. (2008). Considering Students' Perceptions: The Distance Education Student Satisfaction Model. Educational Technology \& Society, 11(3), 216-223. Retrieved from http://www.ifets.info/journals/11_3/15.pdf

Saunders, M., Lewis, P., \& Thornhill, A. (2011). Research Methods for Business Students Fifth edition. India: Dorling Kindersley India Pvt. Ltd.

Sembiring, M. G. (2015 ). Student Satisfaction and Persistence: Imperative Features for Retention in Open and Distance Learning. Asian Association of Open Universities, 10(1), 1-11.

Simpson, O. (2013, March 08). E-Learning and the Future of Distance Education. UK. Retrieved 08 25, 2014 , from

http://www.ormondsimpson.com/USERIMAGES/E-learning\%20and\%20the\%20future\%20of\%20distance $\% 20$ education.pdf

Simpson, O. (Feb 17, 2016). Student Support Service for Success in Open and Distance Learning. A report in the Commonwealth Educational Media Centre for Asia (CEMCA)'EdTech Notes'. Retrieved from http://www.mrsite.co.uk/usersitesv31/94669.mrsite.com/wwwroot/USERIMAGES/Student\%20Support\%2 0Services\%20for\%20Success\%20in\%20ODL.pdf

Statistical Handbook - 2013- Open University of Sri Lanka (OUSL). (July 2014). The Open University of Sri Lanka.

Statistical Handbook 2013. (2014, July). Open University of Sri Lanka. Retrieved 02 08, 2015, from www.ou.ac.lk

Stodnick, M., \& Rogers, P. (January 2008). Using SERVQUAL to Measure the Quality of the Classroom Experience. Decision Sciences Journal of Innovative Education, 6(1).

Strachota, E. (2006). The Use of Survey Research to Measure Student Satisfaction in Online Courses. Midwest Research-to-Practice Conference in Adult, Continuing, and Community Education, University of Missouri-St. Louis, MO, October 4-6, 2, (pp. 1-6). Retrieved 10 21, 2014, from https://pdfs.semanticscholar.org/4ca1/17aea5a58c5426420e4989d974134de38b1d.pdf

Strategic Management Plan 2015 - 2020. (2014). The Open University of Sri Lanka. Retrieved from www.ou.ac.lk/publications/smp

Tinto, V. (2006-2007). Research and Practice of Student Retention: What Next?*. J. College Student Retention, $8(1), 1-19$.

Twaissi, N. M., \& Al-Kilani, M. H. (2015). The Impact of Perceived Service Quality on Students ${ }^{e e}$ Intentions in Higher Education in a Jordanian Governmental University. International Business Research, 8(5), 81-92. doi::10.5539/ibr.v8n5p81

Udo, G. J., Bagchi, K. K., \& Kirs, P. J. (2008). Assessing Web Service Quality Dimensions: The E- Servperf Approach. Issues in Information Systems, IX( 2), 313-322.

Udo, G. J., Bagchi, K. K., \& Kirs, P. J. (2011). Using SERVQUAL to assess the quality of e-learning experience. Computers in Human Behavior, 27, 1272-1283.

Völckner, F., Sattler, H., Hennig-Thurau, T., \& Ringle, C. M. (2010, June 14). The Role of Parent Brand Quality for Service Brand Extension Success. Journal of Service Research. https://doi.org/10.1177/1094670510370054

Wei, C. C., \& Ramalu, S. S. (2011). Students Satisfaction towards the University: Does Service Quality Matters? International Journal of Education, 3(2 : E15), 1-15. https://doi.org/10.5296/ije.v3i2.1065 
Wijesiri, B. (2016). Assessment of Factors Causing Student Satisfaction upon Service Delivery in the Newish Universities in Sri Lanka. Wayamba Journal of Management, 4(2), 1-8.

Wong, K. K.-K. (2013). Partial Least Squares Structural Equation Modeling (PLS-SEM) Techniques Using SmartPLS. Marketing Bulletin, 24(Technical Note 1), 1-32. Retrieved from http://marketing-bulletin.massey.ac.nz

Yang, Z., \& Peterson, R. T. (2004, October). Psychology \& Marketing. 21(10), 799-822. https://doi.org/10.1002/mar.20030

ZeithamI, V., Berry, L. L., \& Parasuraman, A. (1996, April). The Behavioral Consequences of Service Quality. Journal of Marketing, 60, 32-46.

Zeithaml, V. (1988, April). Consumer Perceptions of Price, Quality, and Value: A Means-End Model and Synthesis of Evidence. Journal of Marketing, 52, 2-22. https://doi.org/10.2307/1251446

Zhang, X., Prybutok, V., \& Huang, A. (2006). An empirical study of factors affecting e-service satisfaction. Human Systems Management, 25, 279-291.

\section{Appendix A}

Measurement Model; Outer Loadings

\begin{tabular}{|c|c|c|c|c|c|c|c|}
\hline Item & Assurance & Empathy & Service Quality & Reliability & Responsiveness & Satisfaction & Website Content \\
\hline ASS1P & 0.781 & & & & & & \\
\hline ASS2P & 0.802 & & & & & & \\
\hline ASS3P & 0.732 & & & & & & \\
\hline ASS4P & 0.779 & & & & & & \\
\hline ASS5P & 0.733 & & & & & & \\
\hline ASS6P & 0.722 & & & & & & \\
\hline ASS7P & 0.655 & & & & & & \\
\hline EMP1P & & 0.824 & & & & & \\
\hline EMP2P & & 0.808 & & & & & \\
\hline EMP3P & & 0.856 & & & & & \\
\hline EMP4P & & 0.738 & & & & & \\
\hline EMP5P & & 0.660 & & & & & \\
\hline EMP6P & & 0.668 & & & & & \\
\hline OLQ1P & & & 0.860 & & & & \\
\hline OLQ2P & & & 0.878 & & & & \\
\hline OLQ3P & & & 0.818 & & & & \\
\hline REL1P & & & & 0.795 & & & \\
\hline REL2P & & & & 0.705 & & & \\
\hline REL3P & & & & 0.785 & & & \\
\hline REL4P & & & & 0.705 & & & \\
\hline REL5P & & & & 0.684 & & & \\
\hline REL6P & & & & 0.620 & & & \\
\hline REL7P & & & & 0.688 & & & \\
\hline RES1P & & & & & 0.821 & & \\
\hline RES2P & & & & & 0.801 & & \\
\hline RES3P & & & & & 0.809 & & \\
\hline RES4P & & & & & 0.775 & & \\
\hline
\end{tabular}




\begin{tabular}{lll}
\hline RES5P & 0.767 & \\
RES6P & 0.625 & \\
SAF1P & & 0.773 \\
SAF2P & 0.717 \\
SAF3P & 0.738 \\
SAF4P & 0.714 \\
SAF5P & 0.780 \\
SAF6P & 0.747 & \\
SAF7P & 0.731 & \\
SAF8P & 0.669 & \\
SAF9P & 0.666 & \\
WCS1P & & 0.786 \\
WCS2P & & 0.795 \\
WCS3P & & 0.805 \\
WCS4P & & 0.733 \\
WCS5P & & 0.791 \\
WCS6P & & 0.797 \\
WCS7P & & 0.766 \\
WCS8P & & 0.786 \\
\hline
\end{tabular}

\section{Appendix B}

Measurement Model; Construct Reliability and Validity

\begin{tabular}{llll}
\hline Construct & Cronbach's Alpha & Composite Reliability & Average Variance Extracted (AVE) \\
\hline Assurance & 0.867 & 0.897 & 0.555 \\
Empathy & 0.860 & 0.892 & 0.582 \\
Service Quality & 0.812 & 0.888 & 0.727 \\
Reliability & 0.863 & 0.896 & 0.592 \\
Responsiveness & 0.839 & 0.879 & 0.510 \\
Satisfaction & 0.888 & 0.910 & 0.529 \\
Website Content & 0.910 & 0.927 & 0.613 \\
\hline
\end{tabular}

\section{Appendix C}

Measurement Model; Cross Loadings

\begin{tabular}{llllllll}
\hline Item & Assurance & Empathy & Service Quality & Reliability & Responsiveness & Satisfaction & Website Content \\
\hline ASS1P & 0.781 & 0.454 & 0.150 & 0.339 & 0.401 & 0.298 & 0.238 \\
ASS2P & 0.802 & 0.478 & 0.178 & 0.319 & 0.395 & 0.306 & 0.254 \\
ASS3P & 0.732 & 0.399 & 0.196 & 0.292 & 0.411 & 0.226 & 0.166 \\
ASS4P & 0.779 & 0.486 & 0.180 & 0.375 & 0.449 & 0.263 & 0.279 \\
ASS5P & 0.733 & 0.457 & 0.148 & 0.288 & 0.408 & 0.217 & 0.216 \\
ASS6P & 0.722 & 0.450 & 0.070 & 0.239 & 0.356 & 0.202 & 0.184 \\
ASS7P & 0.655 & 0.399 & 0.148 & 0.282 & 0.356 & 0.217 & 0.188 \\
EMP1P & 0.562 & 0.824 & 0.216 & 0.397 & 0.538 & 0.315 & 0.273 \\
EMP2P & 0.453 & 0.808 & 0.200 & 0.332 & 0.500 & 0.193 & 0.173 \\
EMP3P & 0.517 & 0.856 & 0.159 & 0.379 & 0.518 & 0.259 & 0.282 \\
EMP4P & 0.461 & 0.738 & 0.089 & 0.280 & 0.434 & 0.196 & 0.250 \\
\hline
\end{tabular}




\begin{tabular}{|c|c|c|c|c|c|c|c|}
\hline EMP5P & 0.291 & 0.660 & 0.177 & 0.216 & 0.442 & 0.111 & 0.073 \\
\hline EMP6P & 0.375 & 0.668 & 0.119 & 0.235 & 0.459 & 0.078 & 0.059 \\
\hline OLQ1P & 0.213 & 0.193 & 0.860 & 0.391 & 0.266 & 0.479 & 0.401 \\
\hline OLQ2P & 0.198 & 0.185 & 0.878 & 0.331 & 0.217 & 0.450 & 0.355 \\
\hline OLQ3P & 0.120 & 0.178 & 0.818 & 0.365 & 0.234 & 0.370 & 0.341 \\
\hline REL1P & 0.404 & 0.430 & 0.364 & 0.795 & 0.478 & 0.518 & 0.377 \\
\hline REL2P & 0.294 & 0.262 & 0.320 & 0.705 & 0.354 & 0.370 & 0.213 \\
\hline REL3P & 0.366 & 0.348 & 0.296 & 0.785 & 0.396 & 0.464 & 0.359 \\
\hline REL4P & 0.334 & 0.299 & 0.244 & 0.705 & 0.320 & 0.405 & 0.363 \\
\hline REL5P & 0.182 & 0.188 & 0.309 & 0.684 & 0.331 & 0.304 & 0.270 \\
\hline REL6P & 0.186 & 0.241 & 0.312 & 0.620 & 0.354 & 0.214 & 0.247 \\
\hline REL7P & 0.241 & 0.272 & 0.288 & 0.688 & 0.325 & 0.401 & 0.366 \\
\hline RES1P & 0.514 & 0.562 & 0.287 & 0.463 & 0.821 & 0.387 & 0.293 \\
\hline RES2P & 0.418 & 0.500 & 0.196 & 0.402 & 0.801 & 0.247 & 0.186 \\
\hline RES3P & 0.441 & 0.494 & 0.173 & 0.391 & 0.809 & 0.230 & 0.172 \\
\hline RES4P & 0.361 & 0.465 & 0.181 & 0.401 & 0.775 & 0.234 & 0.159 \\
\hline RES5P & 0.401 & 0.505 & 0.193 & 0.382 & 0.767 & 0.189 & 0.148 \\
\hline RES6P & 0.256 & 0.348 & 0.234 & 0.307 & 0.625 & 0.120 & 0.056 \\
\hline SAF1P & 0.310 & 0.321 & 0.467 & 0.447 & 0.317 & 0.773 & 0.506 \\
\hline SAF2P & 0.251 & 0.244 & 0.354 & 0.353 & 0.239 & 0.717 & 0.535 \\
\hline SAF3P & 0.224 & 0.228 & 0.412 & 0.388 & 0.256 & 0.738 & 0.452 \\
\hline SAF4P & 0.209 & 0.262 & 0.395 & 0.409 & 0.277 & 0.714 & 0.489 \\
\hline SAF5P & 0.303 & 0.185 & 0.396 & 0.479 & 0.242 & 0.780 & 0.472 \\
\hline SAF6P & 0.271 & 0.180 & 0.302 & 0.405 & 0.217 & 0.747 & 0.457 \\
\hline SAF7P & 0.226 & 0.154 & 0.403 & 0.423 & 0.248 & 0.731 & 0.444 \\
\hline SAF8P & 0.230 & 0.108 & 0.302 & 0.359 & 0.175 & 0.669 & 0.370 \\
\hline SAF9P & 0.162 & 0.089 & 0.281 & 0.321 & 0.132 & 0.666 & 0.404 \\
\hline WCS1P & 0.355 & 0.262 & 0.375 & 0.452 & 0.269 & 0.583 & 0.786 \\
\hline WCS2P & 0.281 & 0.218 & 0.347 & 0.367 & 0.179 & 0.535 & 0.795 \\
\hline WCS3P & 0.261 & 0.237 & 0.424 & 0.369 & 0.246 & 0.518 & 0.805 \\
\hline WCS4P & 0.198 & 0.201 & 0.367 & 0.294 & 0.196 & 0.421 & 0.733 \\
\hline WCS5P & 0.175 & 0.216 & 0.299 & 0.315 & 0.169 & 0.486 & 0.791 \\
\hline WCS6P & 0.180 & 0.177 & 0.289 & 0.321 & 0.116 & 0.447 & 0.797 \\
\hline WCS7P & 0.170 & 0.131 & 0.282 & 0.310 & 0.135 & 0.458 & 0.766 \\
\hline WCS8P & 0.193 & 0.204 & 0.288 & 0.323 & 0.148 & 0.493 & 0.786 \\
\hline
\end{tabular}

\section{Appendix D}

Measurement Model; Fornell-Larcker Criterion

\begin{tabular}{llllllll}
\hline Construct & Assurance & Empathy & $\begin{array}{c}\text { Service } \\
\text { Quality }\end{array}$ & Reliability & Responsiveness & Satisfaction & $\begin{array}{c}\text { Website } \\
\text { Content }\end{array}$ \\
\hline Assurance & 0.745 & & & & & \\
Empathy & 0.598 & 0.763 & & & & \\
Service Quality & 0.210 & 0.218 & 0.852 & & & \\
Reliability & 0.533 & 0.632 & 0.281 & 0.769 & & \\
Responsiveness & 0.414 & 0.419 & 0.426 & 0.516 & 0.714 & 0.727 & 0.783 \\
Satisfaction & 0.337 & 0.278 & 0.511 & 0.327 & 0.551 & 0.634 & \\
Website Content & 0.297 & 0.266 & 0.431 & 0.238 & 0.445 & & \\
\hline
\end{tabular}




\section{Appendix E}

Heterotrait-Monotrait (HTMT) values

\begin{tabular}{|c|c|c|c|c|c|}
\hline Relationship & $\begin{array}{l}\text { Original } \\
\text { Sample } \\
(\mathrm{O})\end{array}$ & $\begin{array}{l}\text { Sample } \\
\text { Mean } \\
(\mathrm{M})\end{array}$ & Bias & $2.5 \%$ & $97.5 \%$ \\
\hline Empathy -> Assurance & 0.671 & 0.670 & -0.001 & 0.605 & 0.734 \\
\hline Overall Service Quality -> Assurance & 0.241 & 0.243 & 0.002 & 0.151 & 0.334 \\
\hline Overall Service Quality -> Empathy & 0.250 & 0.251 & 0.001 & 0.162 & 0.338 \\
\hline Reliability -> Assurance & 0.597 & 0.597 & -0.001 & 0.524 & 0.667 \\
\hline Reliability -> Empathy & 0.722 & 0.723 & 0.000 & 0.661 & 0.782 \\
\hline Reliability -> Overall Service Quality & 0.326 & 0.326 & 0.000 & 0.241 & 0.409 \\
\hline Responsiveness -> Assurance & 0.465 & 0.465 & 0.000 & 0.374 & 0.554 \\
\hline Responsiveness -> Empathy & 0.462 & 0.462 & 0.000 & 0.380 & 0.540 \\
\hline Responsiveness -> Overall Service Quality & 0.516 & 0.517 & 0.000 & 0.436 & 0.596 \\
\hline Responsiveness -> Reliability & 0.593 & 0.594 & 0.000 & 0.517 & 0.664 \\
\hline Satisfaction $->$ Assurance & 0.374 & 0.375 & 0.001 & 0.288 & 0.459 \\
\hline Satisfaction -> Empathy & 0.283 & 0.290 & 0.007 & 0.211 & 0.350 \\
\hline Satisfaction -> Overall Service Quality & 0.592 & 0.593 & 0.001 & 0.512 & 0.664 \\
\hline Satisfaction -> Reliability & 0.342 & 0.343 & 0.001 & 0.260 & 0.417 \\
\hline Satisfaction $->$ Responsiveness & 0.617 & 0.618 & 0.001 & 0.543 & 0.686 \\
\hline Website Content $->$ Assurance & 0.322 & 0.323 & 0.001 & 0.231 & 0.409 \\
\hline Website Content -> Empathy & 0.271 & 0.277 & 0.006 & 0.198 & 0.344 \\
\hline Website Content -> Overall Service Quality & 0.494 & 0.495 & 0.001 & 0.416 & 0.568 \\
\hline Website Content -> Reliability & 0.249 & 0.252 & 0.003 & 0.172 & 0.322 \\
\hline Website Content $->$ Responsiveness & 0.498 & 0.498 & 0.001 & 0.412 & 0.574 \\
\hline Website Content $->$ Satisfaction & 0.697 & 0.697 & 0.000 & 0.637 & 0.751 \\
\hline
\end{tabular}

\section{Appendix F}

VIF and Tolerance Values of the conceptual model

\begin{tabular}{lllll}
\hline & \multicolumn{2}{l}{ VIF } & \multicolumn{2}{l}{ Tolerance(1/VIF) } \\
\hline Construct & $\begin{array}{l}\text { Service } \\
\text { Quality }\end{array}$ & Satisfaction & Service & Satisfaction \\
& 1.721 & 1.722 & 0.581058 & 0.58072 \\
Assurance & 1.997 & 1.997 & 0.500751 & 0.500751 \\
Empathy & & 1.351 & & 0.740192 \\
Service Quality & & 2.003 & 0.503018 & 0.499251 \\
Reliability & 1.988 & 1.721 & 0.581058 & 0.58072 \\
Responsiveness & 1.631 & 1.405 & 0.500751 & 0.500751 \\
Website Content & 1.278 & & &
\end{tabular}




\section{Appendix G}

Structural model step1; Path Coefficients

\begin{tabular}{llllll}
\hline Relationship & $\begin{array}{l}\text { Original } \\
\text { Sample } \\
(\mathrm{O})\end{array}$ & $\begin{array}{l}\text { Sample } \\
\text { Mean } \\
(\mathrm{M})\end{array}$ & $\begin{array}{l}\text { Standard } \\
\text { Deviation } \\
(\mathrm{STDEV})\end{array}$ & $\begin{array}{l}\mathrm{T} \\
(|\mathrm{O} / \mathrm{STDEV}|)\end{array}$ & $\begin{array}{l}\text { Statistics } \\
\text { Values }\end{array}$ \\
\hline Assurance -> Service Quality & -0.031 & -0.030 & 0.046 & 0.671 & 0.502 \\
Assurance -> Satisfaction & 0.082 & 0.082 & 0.038 & 2.166 & 0.030 \\
Empathy -> Service Quality & -0.018 & -0.016 & 0.047 & 0.377 & 0.706 \\
Empathy -> Satisfaction & -0.049 & -0.047 & 0.037 & 1.335 & 0.182 \\
Service Quality -> Satisfaction & 0.212 & 0.213 & 0.036 & 5.836 & 0.000 \\
Responsiveness -> Service Quality & 0.103 & 0.103 & 0.045 & 2.301 & 0.021 \\
Responsiveness -> Satisfaction & 0.027 & 0.026 & 0.040 & 0.684 & 0.494 \\
Reliability -> Service Quality & 0.257 & 0.257 & 0.045 & 5.700 & 0.000 \\
Reliability -> Satisfaction & 0.249 & 0.250 & 0.039 & 6.325 & 0.000 \\
Website Content -> Service Quality & 0.306 & 0.306 & 0.041 & 7.547 & 0.000 \\
website Content -> Satisfaction & 0.414 & 0.414 & 0.041 & 10.156 & 0.000 \\
\hline
\end{tabular}

\section{Appendix $\mathrm{H}$}

Collinearity Statistics (VIF)

\begin{tabular}{lll}
\hline & Service Quality & Satisfaction \\
\hline Service Quality & & 1.314 \\
Reliability & 1.510 & 1.292 \\
Responsiveness & 1.333 & \\
Satisfaction & & \\
Website Content & 1.213 & 1.349 \\
\hline
\end{tabular}

\section{Appendix I}

Final Structural Model; Path Coefficients

\begin{tabular}{llllll}
\hline Relationship & $\begin{array}{l}\text { Original } \\
\text { Sample } \\
(\mathrm{O})\end{array}$ & $\begin{array}{l}\text { Sample } \\
\text { Mean } \\
(\mathrm{M})\end{array}$ & $\begin{array}{l}\text { Standard } \\
\text { Deviation } \\
(\mathrm{STDEV})\end{array}$ & $\begin{array}{l}\mathrm{T} \\
(|\mathrm{O} / \mathrm{STDEV}|)\end{array}$ & $\begin{array}{c}\text { Statistics } \\
\mathrm{P} \\
\text { Values }\end{array}$ \\
\hline Service Quality -> Satisfaction & 0.224 & 0.224 & 0.034 & 6.574 & 0.000 \\
Reliability -> Service Quality & 0.214 & 0.213 & 0.043 & 4.930 & 0.000 \\
Reliability -> Satisfaction & 0.301 & 0.300 & 0.034 & 8.788 & 0.000 \\
Responsiveness -> Service Quality & 0.079 & 0.082 & 0.035 & 2.240 & 0.026 \\
Website Content -> Service Quality & 0.323 & 0.325 & 0.039 & 8.223 & 0.000 \\
Website Content -> Satisfaction & 0.415 & 0.416 & 0.039 & 0.669 & 0.000 \\
Assurance -> Satisfaction & 0.049 & 0.051 & 0.028 & 1.745 & 0.081 \\
\hline
\end{tabular}




\section{Appendix $\mathrm{J}$}

Final Model; R Square

\begin{tabular}{llllll}
\hline Construct & $\begin{array}{l}\text { Original } \\
\text { Sample }(\mathrm{O})\end{array}$ & $\begin{array}{l}\text { Sample } \\
\text { Mean }(\mathrm{M})\end{array}$ & $\begin{array}{l}\text { Standard } \\
\text { Deviation } \\
\text { (STDEV) }\end{array}$ & $\begin{array}{l}\mathrm{T} \text { Statistics } \\
(|\mathrm{O} / \mathrm{STDEV}|)\end{array}$ & $\begin{array}{l}\mathrm{P} \\
\text { Values }\end{array}$ \\
\hline Service Quality & 0.244 & 0.249 & 0.029 & 8.384 & 0.000 \\
Satisfaction & 0.549 & 0.553 & 0.027 & 20.635 & 0.000 \\
\hline
\end{tabular}

\section{Appendix K}

Final Model; Average Variance Extracted (AVE)

\begin{tabular}{llllll}
\hline Construct & $\begin{array}{l}\text { Original } \\
\text { Sample } \\
(\mathrm{O})\end{array}$ & $\begin{array}{l}\text { Sample } \\
\text { Mean } \\
(\mathrm{M})\end{array}$ & $\begin{array}{l}\text { Standard } \\
\text { Deviation } \\
(\mathrm{STDEV})\end{array}$ & $\begin{array}{l}\mathrm{T} \text { Statistics } \\
(|\mathrm{O} / \mathrm{STDEV}|)\end{array}$ & $\begin{array}{l}\mathrm{P} \\
\text { Values }\end{array}$ \\
\hline Service Quality & 0.726 & 0.726 & 0.015 & 47.659 & 0.000 \\
Reliability & 0.636 & 0.636 & 0.017 & 36.395 & 0.000 \\
Responsiveness & 0.642 & 0.641 & 0.017 & 37.848 & 0.000 \\
Satisfaction & 0.568 & 0.568 & 0.018 & 31.879 & 0.000 \\
Website Content & 0.612 & 0.612 & 0.017 & 35.150 & 0.000 \\
\hline
\end{tabular}

Appendix L

Final Model; Composite Reliability

\begin{tabular}{llllll}
\hline Construct & $\begin{array}{l}\text { Original } \\
\text { Sample } \\
(\mathrm{O})\end{array}$ & $\begin{array}{l}\text { Sample } \\
\text { Mean } \\
(\mathrm{M})\end{array}$ & $\begin{array}{l}\text { Standard } \\
\text { Deviation } \\
(\mathrm{STDEV})\end{array}$ & $\begin{array}{l}\mathrm{T} \text { Statistics } \\
(|\mathrm{O} / \mathrm{STDEV}|)\end{array}$ & $\begin{array}{l}\mathrm{P} \\
\text { Values }\end{array}$ \\
\hline Service Quality & 0.888 & 0.888 & 0.008 & 116.142 & 0.000 \\
Reliability & 0.874 & 0.874 & 0.008 & 104.292 & 0.000 \\
Responsiveness & 0.900 & 0.899 & 0.007 & 132.649 & 0.000 \\
Satisfaction & 0.902 & 0.902 & 0.006 & 139.733 & 0.000 \\
Website Content & 0.927 & 0.926 & 0.005 & 184.473 & 0.000 \\
\hline
\end{tabular}

\section{Appendix M}

Final Model; Cronbach's Alpha

\begin{tabular}{llllll}
\hline Construct & $\begin{array}{l}\text { Original } \\
\text { Sample } \\
(\mathrm{O})\end{array}$ & $\begin{array}{l}\text { Sample } \\
\text { Mean } \\
(\mathrm{M})\end{array}$ & $\begin{array}{l}\text { Standard } \\
\text { Deviation } \\
(\mathrm{STDEV})\end{array}$ & $\begin{array}{l}\mathrm{T} \text { Statistics } \\
(|\mathrm{O} / \mathrm{STDEV}|)\end{array}$ & $\begin{array}{l}\mathrm{P} \\
\text { Values }\end{array}$ \\
\hline Service Quality & 0.812 & 0.812 & 0.014 & 56.548 & 0.000 \\
Reliability & 0.809 & 0.809 & 0.014 & 55.819 & 0.000 \\
Responsiveness & 0.862 & 0.862 & 0.010 & 87.472 & 0.000 \\
Satisfaction & 0.873 & 0.873 & 0.009 & 94.329 & 0.000 \\
Web Site Content & 0.910 & 0.910 & 0.007 & 138.146 & 0.000 \\
\hline
\end{tabular}




\section{Appendix N}

Final Model; Heterotrait-Monotrait Ratio (HTMT)

\begin{tabular}{lllll}
\hline Relationship & $\begin{array}{l}\text { Original } \\
\text { Sample } \\
(\mathrm{O})\end{array}$ & $\begin{array}{l}\text { Sample } \\
\text { Mean } \\
(\mathrm{M})\end{array}$ & $2.5 \%$ & $97.5 \%$ \\
\hline Reliability -> Overall Service Quality & 0.472 & 0.472 & 0.386 & 0.557 \\
Responsiveness -> Service Quality & 0.306 & 0.307 & 0.220 & 0.393 \\
Responsiveness -> Reliability & 0.578 & 0.578 & 0.504 & 0.650 \\
Satisfaction -> Service Quality & 0.610 & 0.611 & 0.536 & 0.683 \\
Satisfaction -> Reliability & 0.656 & 0.656 & 0.580 & 0.728 \\
Satisfaction -> Responsiveness & 0.388 & 0.388 & 0.305 & 0.467 \\
Website Content -> Service Quality & 0.494 & 0.495 & 0.417 & 0.571 \\
Website Content -> Reliability & 0.472 & 0.472 & 0.391 & 0.553 \\
Website Content -> Responsiveness & 0.264 & 0.265 & 0.180 & 0.350 \\
Website Content -> Satisfaction & 0.707 & 0.708 & 0.650 & 0.761 \\
\hline
\end{tabular}

Appendix O Survey Instrument

\begin{tabular}{llll}
\hline Item of Source & Operational Component & Measurement \\
Concept & & & Scale \\
\hline
\end{tabular}

\section{SERVICE QUALITY DIMENSIONS}

1. Assurance: Which is an indication of the knowledge and courtesy of Staff/Instructors and their ability to inspire trust and confidence for the students

ASS1.

(Udo et al.,2011;

The instructor is knowledgeable in his/her field

Likert scale (1.5)

Mantovani ,2012)

ASS2. (Udo et al.,2011; Ali \& Ahmad, The instructor is fair and impartial in grading

2011;Mantovani, 2012)

ASS3.

(Udo et al.,2011;

Mantovani, 2012)

ASS4. (Udo et al.,2011

Mantovani, 2012 Amended)

ASS $5 \quad$ (Ali \& Ahmad, 2011)

The instructor answers all the questions thoroughly

I am confident the instructor has an expert understanding of the materials

The instructors informed me about my progress periodically

I am assured of a reputed and acceptable qualification

ASS 6 (Joseph and Joseph, 1997 modified)

Assurance with updated programmes and curriculum

ASS 7

By the Author

2. Empathy: which includes caring and individualized attention that the university provides to its students.

EMP1 (Mantovani, 2012; Stodnick \& Rogers, 2008; The instructor is genuinely concerned about the students. Likert scale(1..5) Udo et al.,2011)

EMP2 (Mantovani, 2012; Udo et al.,2011; Stodnick students. \& Rogers,2008)

The instructor understands the individual needs of

The instructor has the student's best long-term interests

EMP3

(Mantovani, 2012; Udo et al.,2011; Stodnick in mind.

\& Rogers,2008) 


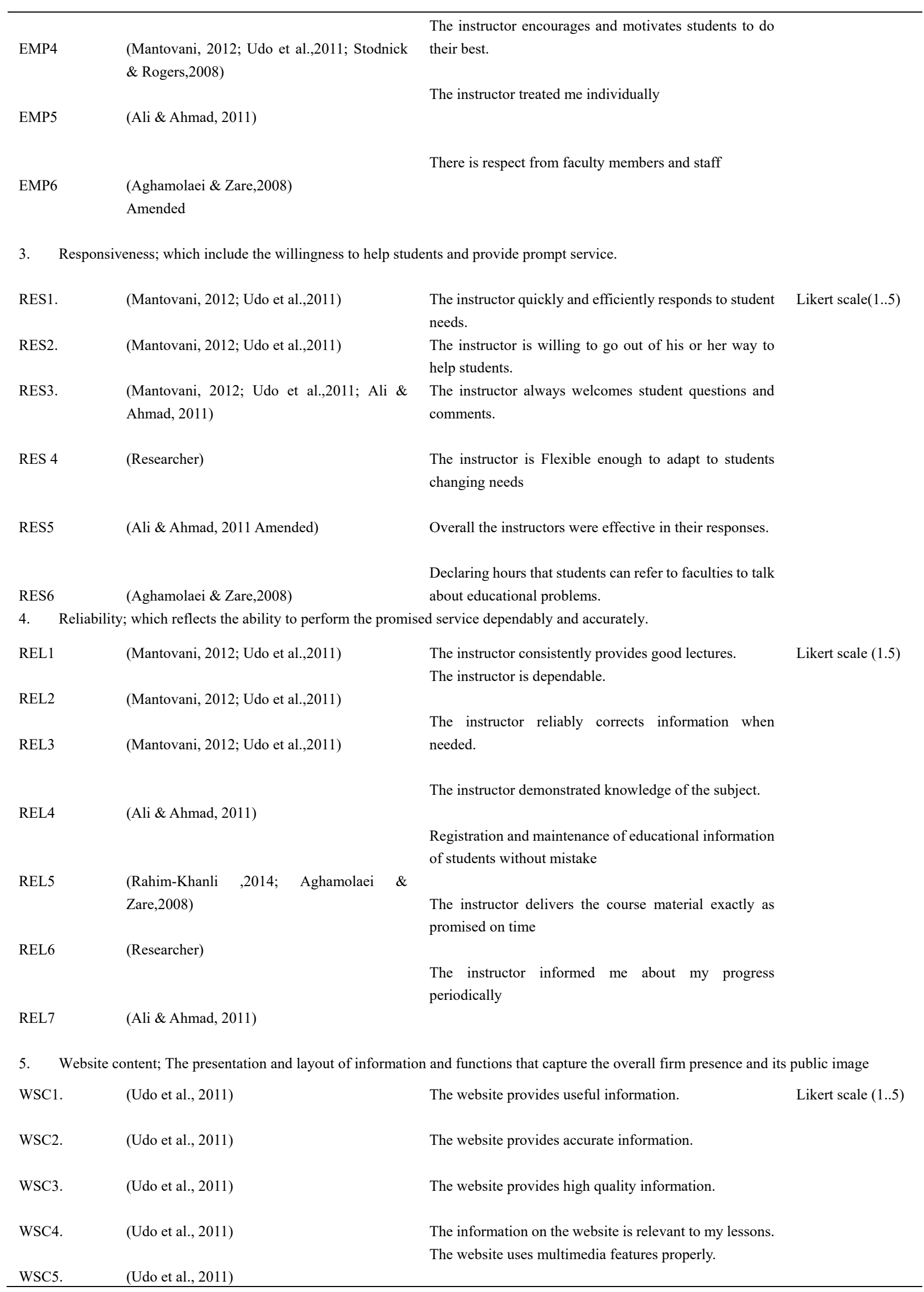




\begin{tabular}{|c|c|c|c|}
\hline \multirow{3}{*}{ WSC6. } & \multirow[b]{2}{*}{ (Udo et al., 2011) } & \multicolumn{2}{|l|}{ The website uses animations/graphics properly. } \\
\hline & & & \\
\hline & & \multicolumn{2}{|l|}{ The website uses audio elements properly. } \\
\hline \multirow[t]{2}{*}{ WSC7. } & (Udo et al., 2011) & & \\
\hline & & \multicolumn{2}{|l|}{ The website uses video elements properly. } \\
\hline WSC8. & \multicolumn{3}{|l|}{ (Udo et al.,2011) } \\
\hline \multicolumn{4}{|c|}{$\begin{array}{l}\text { 6. Perceived Service Quality; Reflect perceptions of quality, clarity of instruction, currency of information, and functionality of the features on } \\
\text { the website. }\end{array}$} \\
\hline \multicolumn{4}{|c|}{ OLQ1 (Udo et al.,2011) Over all service quality is excellent Likert scale (1..5) } \\
\hline \multicolumn{4}{|c|}{ OLQ2 (Researcher) Overall quality of the course content is satisfactory } \\
\hline \multicolumn{4}{|c|}{ OLQ3 (Researcher) Excellent service quality offered compare to other institutions } \\
\hline \multicolumn{4}{|c|}{$\begin{array}{l}\text { 7. Satisfaction: The overall assessment of the student's distance learning experience, including overall pleasure and satisfaction with the service } \\
\text { received. }\end{array}$} \\
\hline SAT1 & (Udo et al.,2011) & $\begin{array}{l}\text { Would you agree to say that "I am satisfied with my decision } \\
\text { to enroll with this distance programme" }\end{array}$ & $\begin{array}{l}\text { Likert } \\
\text { scale(1..5) }\end{array}$ \\
\hline SAT2 & (Udo et al.,2011) & $\begin{array}{l}\text { Would you agree to say that "My choice to enroll this } \\
\text { programme was a wise one?" }\end{array}$ & \\
\hline SAT3 & (Udo et al.,2011) & $\begin{array}{l}\text { Would you agree to say that "I think I did the right thing } \\
\text { when I paid for this learning service?" }\end{array}$ & \\
\hline SAT4 & (Udo et al.,2011) & $\begin{array}{l}\text { Would you agree to say that "I feel that my experience with } \\
\text { distance learning has been enjoyable?" }\end{array}$ & \\
\hline SAT5 & (Gruber et al, 2010; Mantovani, 2012) & This distance learning course meets my expectations. & \\
\hline SAT6 & (Yang et al. (2004) amended & My Overall experience is better than I originally anticipated. & \\
\hline SAT7 & (Yang et al. (2004) amended & $\begin{array}{l}\text { I am Overall satisfied with the programmes and services } \\
\text { offered by the Institute. }\end{array}$ & \\
\hline SAT8 & (Researcher) & $\begin{array}{l}\text { I am satisfied with the distance course since it will give me a } \\
\text { better chance in my career development. }\end{array}$ & \\
\hline SAT9 & (Researcher) & I am delighted with the distance course and its contents. & \\
\hline
\end{tabular}

\section{Copyrights}

Copyright for this article is retained by the author(s), with first publication rights granted to the journal.

This is an open-access article distributed under the terms and conditions of the Creative Commons Attribution license (http://creativecommons.org/licenses/by/4.0/). 